\title{
The road to the Sustainable Development Goals: building global alliances and norms
}

\section{Des Gasper}

To cite this article: Des Gasper (2019) The road to the Sustainable Development Goals: building global alliances and norms, Journal of Global Ethics, 15:2, 118-137, DOI: 10.1080/17449626.2019.1639532

To link to this article: https://doi.org/10.1080/17449626.2019.1639532

册 Published online: 30 Jul 2019.

Submit your article to this journal $\asymp$

山ll Article views: 231

Q View related articles ๘

View Crossmark data 


\title{
The road to the Sustainable Development Goals: building global alliances and norms
}

\author{
Des Gasper \\ International Institute of Social Studies, Erasmus University Rotterdam, The Hague, The Netherlands
}

\begin{abstract}
Several insider accounts of the formation of the Sustainable Development Goals suggest that the process (the procedures used and the emergent organizational and governance system features) was as important as the resulting goal-set. The paper looks at both aspects, and relationships between them: the rising influence of Southern nations (seen in the roles played by Colombia, Brazil, some African countries and the G77); the partial transcendence of traditional inter-bloc negotiation, including through adoption of elements of deliberative decision-making; the major involvement of civil society and business organizations, thanks especially to the IT revolution; the adoption of a goalstargets-indicators frame that has flexibility at national level and implicit reliance on intensive further civil society activism and monitoring. The paper considers these features and the implied prospects for the SDGs in relation to various perspectives on global governance, with special reference to norm-setting: Ruggie's concepts of 'global public domain' and 'polycentric global governance', Risse and Sikkink's 'norms cascade', Murphy's posited required elements for progressive global innovation, and Raskin's model of transition through responses to crises. It concludes with questions for further work, including regarding the possibly problematic absence of an explicit inspirational value-core.
\end{abstract}

\section{ARTICLE HISTORY}

Received 16 January 2019

Accepted 1 July 2019

\section{KEYWORDS}

Sustainable Development Goals; global governance; global norms; global public domain; global transition

\section{Themes and overview}

The contents of the Sustainable Development Goals (SDGs) are in various respects limited and problematic. ${ }^{1}$ However, the process through which they emerged is equally important and carries implications for their long-run potential. Studying this process has lessons for thinking about global ethics in practice, not only in abstracted idealized theorizing. For example, much discussion of alliances focuses on personal links and interpersonal trust, but for global challenges we must consider also relationships that are indirect, impersonal and work via very large systems. Human rights discourse is good for many roles here but has major limits too. The Sustainable Development Goals (SDGs) are a set of global aspirational goals that are complementary to and sometimes more specific than human rights and are partly focused via targets and indicators. I will discuss the formation of the SDGs as an attempt to stimulate and coordinate progressive action and cooperation 
worldwide, and the systems of alliances that emerged to articulate, negotiate, and promulgate the goals. Webs of personal relations played a role, but within systems of institutionalized relationships.

Current global economic development is not sustainable, but the economic growth imperatives in capitalism, plus techno-optimism, market theology, and nationalist identities, ambitions and rivalries, mean that denial, inattention, and non-preparation prevail (Gasper 2019). Ignorance about other people adds to and reinforces indifference, antagonism, and even malice towards them, hindering the cooperation and preparations needed for a sustainable world. Crisis becomes thereby an inevitable phase before any fundamental change.

Although necessary, crisis is insufficient; it can provoke fear, hate, and increased selfishness. Various authors (e.g. Raskin 2016) identify elements necessary for an effective progressive response. Murphy (2005) suggests the following: wideranging networks must have formed, be motivated by plausible and inspiring values and a vision of a better future, have produced practicable ideas for action, and have established links to potentially sympathetic decision-makers, so as to be ready when opportunities arise as crises emerge and grow. In addition, the activists for change must be alert, active, realistic, and decisive when times of crisis-cum-opportunity arrive.

We can see such elements at work in the spread of human rights ideas. In the model of the 'human rights cascade', ideas were disseminated and institutionalized globally in the late twentieth century via a 'boomerang effect' that reinforced local campaigns through connection to a 'global human rights polity' headquartered in the North. But whereas the 'human rights cascade' involved simple alliances between local human rights defenders and global supporters referring to authoritative global norms on civil and political rights, already in the case of the human rights responsibilities of international businesses we see more complex 'polycentric global governance', wherein progress has required cooperation between a greater range of actors, mechanisms and norms, and more flexibility and plurality. In addition, the 'boomerangs' sent from the South are now not just calls to the North for help. Instead they are often Southern proposals or models, sent globally; the North-South division has evolved and partly eroded. The SDGs process illustrates this, and also matches Murphy's model regarding necessary elements in change.

This paper looks at the emergence and nature of the SDGs, from the Rio+20 process of 2009-2012, through the 2012 Rio global summit on sustainable development that produced the declaration The Future We Want (United Nations 2012), to the subsequent 2030 Agenda for Sustainable Development (United Nations 2015), agreed in New York by all governments in 2015, that includes the SDGs. Rio+20 and this 2030 Agenda were products of a growing global infrastructure of governmental, private and civil society actors, networks, and values, that have operated to in some ways reform the global power-system and restrain its destructive and damaging tendencies (Dodds, Laguna-Celis, and Thompson 2014; Dodds, Donoghue, and Roesch 2017; Kamau, Chasek, and O'Connor 2018). According to Macharia Kamau - the forceful Kenyan co-chair of the UN's Open Working Group that prepared the main SDGs proposal during 2013-2014 and of the UN General Assembly negotiation process that very largely adopted that proposal in 2015 - more was achieved by this process than almost anyone in 2012 had considered possible (Kamau 2018, xviii): a comprehensive and universal policy agenda and a partly reconfigured system of global governance. The work has to a large extent been led from the 
South, often by actors who have moved between government, international agencies, NGOs, and research. While the contents of the SDGs on paper often fall short, together the contents, process, and systems provide stepping-stones that can help in mitigating and coping with the crises that are likely to unfold (Gasper 2019).

The paper analyses mechanisms and dynamics in the emergence of the SDGs, showing important alliances between states and between state- and non-state actors, but within fluid and flexible 'cooperation regimes' that can fit the requirements and real options for advance in situations of polycentric modern global governance. The analysis of emergence then leads to a series of questions about the SDGs' future potential.

\section{From human rights cascades to polycentric global governance}

The SDGs build on a core of value inspiration provided by human rights ideas, but not exclusively and largely only tacitly. ${ }^{2}$ Human rights ideas and practice illustrate, first, the role of inspirational, value-rich, universal yet action-oriented ideas for national and especially international mobilization and cooperation. They illustrate too, secondly, the need for complementary policy craft and governance craft, to manage differing interpretations of and conflicts amongst these values, in settings where powers of initiative in policy and governance grow in numerous countries, movements, and corporations all over the world. We can see these features in respectively, first, late twentieth century 'human rights cascades' into authoritarian states, and second, current attempts to bring human rights to bear in guiding global businesses.

The 1970s through 1990s saw a striking strengthening of international civil and political human rights norms in many (previously) authoritarian or semi-authoritarian countries. Finnemore and Sikkink (1998) adopted Sunstein's (1997) term 'norms cascade' to describe this process; and Risse and Sikkink (1999) presented an influential model of such 'human rights cascades' (see also Risse, Ropp, and Sikkink 2013). Human rights language plays essential roles in linking diverse global constituencies (Gasper 2006, 2016). It is vivid, morally forceful, sufficiently universally comprehensible and intuitively meaningful, and often indicates responsibilities for specified agents. The strengths are evident when we contrast with a sister example, the Human Development movement in development policy analysis and statistics. While human development thinking adds some required subtlety and flexibility, it lacks such vivid forcefulness and action-oriented specification of rights and duties (Gasper 2007). International agreement and attention became mobilized instead around the needs-based International Development Targets consolidated by OECD in 1996, that evolved into the Millennium Development Goals (MDGs).

Many human rights advocates have been infuriated that the SDGs do not centre on promulgation of human rights conventions and principles. But human rights' very forcefulness and their lack of underlying theoretical agreement bring limits too; rights often conflict, in the short-run or longer-term, and creativity and pragmatism are required for handling the conflicts. Further, only asserting human rights, against the national dreams of aspirant powers and the ambitions of national and global businesses, will frequently fail to produce the required internalization and socialization.

John Ruggie's 'Framework' (Ruggie 2008) and 'Principles' (OHCHR 2011) for business corporations' public responsibilities illustrates a more likely path forward, including modalities similar to those crafted later for the SDGs. Human rights advocates have demanded 
that corporations adopt all the human rights obligations in international human rights law. Businesses replied that they are not governments and that they produce social benefits as a side-effect of making profits, so that they should be left to self-regulate and voluntarily follow self-defined codes. Organized business has had the power and backing to block anything more. In the late 1990s, UN Secretary-General Kofi Annan took a step beyond this deadlock, bringing forward a more ambitious voluntary code, the Global Compact. Through their participation in the Compact, the increasing number of businesses who join for the sake of respectability of their public profile, and thus to insure their business prospects, 'acknowledge that universal principles at least in some measure also encompass the sphere of transnational corporate activity' (Ruggie 2004, 516). In 2005 Annan mandated Ruggie, his chief adviser for the Compact, to lead a second stage.

Ruggie decided not to aim for a perfectionist solution or a special new human rights convention for businesses that would never be agreed upon or sufficiently widely ratified. Instead, he focused on the obligation of businesses to not violate rights specified in the foremost existing agreements. A principle of non-violation is hard for businesses and their backers to object to. In 2008 he presented the Protect, Respect and Remedy Framework. Further, he indicated practical implications of the non-violation principle, and procedures for getting case-by-case negotiated compromises between conflicting objectives, notably in the 2011 Guiding Principles document. By getting practical, including indicating space for crafting worthwhile compromises, and by remaining at the level of 'soft law' norms rather than aiming to be binding 'hard law', the Principles gained a very high, unusual, degree of support both at the intergovernmental level and from corporations.

Reflecting on these experiences, Ruggie offered a theory of polycentric global governance. He noted the co-existence of: first, public law, both national and international, including human rights conventions; second, companies' corporate governance; and third, the civil governance mechanisms by which people affected by business activities try to influence them, including 'campaigns, law suits, and other forms of pressure, but also partnering with companies to induce positive change' $(2015,3)$. His Principles offer a 'basis whereby the three forms of governance systems become better aligned in relation to business and human rights, compensate for one another's shortcomings and begin to play mutually reinforcing roles' $(2015,2)$. Generalizing this perspective, effective polycentric global governance involves connecting to and linking all countries and all major actors - states, businesses, civil society actors - and employs many channels of discourse, contestation, and action. Citing his own earlier work (Ruggie 2004, 519), Ruggie forwards the concept of 'the global public domain' which refers to

an increasingly institutionalized transnational arena of discourse, contestation and action concerning the production of global public goods, involving private as well as public actors. It does not by itself determine global governance outcomes any more than its counterpart does at the domestic level. But it introduces opportunities for and constraints upon both global and national governance that did not exist in the past. $(2015,3)$

The SDGs emerged as a movement in the global public domain that seeks to add ideas, opportunities, incentives, and energies, plus constraints, disciplines, and frameworks into national and corporate governance domains. Like the Ruggie Principles they build on and link existing agreements and fora, while leaving space for case-specific negotiation, adaptation, and innovation. 


\section{Rio+20 and the emergence of the SDGs, 2010-2015}

A set of recent insider accounts tell us much about the SDGs process. Felix Dodds published two books in collaboration with senior participants in the process. From Rio +20 to a New Development Agenda (Dodds, Laguna-Celis, and Thompson 2014) was written with a Mexican government representative and a former government Minister from Barbados who became a UN Assistant Secretary General. The successor book, Negotiating the SDGs (Dodds, Donoghue, and Roesch 2017), about the events of 2014-2015, was written with David Donoghue, the Irish ambassador to the UN who co-facilitated the Inter-Governmental Negotiations of 2014-2015, and Jimena Leiva-Roesch who was a Guatemalan diplomat at the UN. Further, Donoghue and two others - Paula Caballero of Colombia, creator of the SDGs idea, and Olav Kjørven, the lead UNDP official for discussions on the post-2015 agenda - wrote personal accounts of key phases (Donoghue 2016; Caballero 2016; Kjørven 2016). Lastly, the Kenyan UN Ambassador Macharia Kamau, co-chair of both the 2013-2014 and 2014-2015 cycles of negotiation, cooperated with an American academic and a senior ex-UN official to produce Transforming Multilateral Diplomacy: the inside story of the sustainable development goals (2018). Drawing on these and other accounts, we see how the process involved a rise of the influence and effectiveness of Southern actors and at the same time a movement beyond traditional blocs.

\section{'The rise of the South'...}

Countries and individuals from 'the South' played decisive roles in establishing and steering the Rio+20 summit (the UN Conference on Sustainable Development), including inserting the notion of SDGs, and in the Goals' subsequent articulation and approval. Prominent were the governments of Brazil and Colombia; other important players included India, Kenya, Pakistan, South Africa and Uganda, amongst others. Prominent too were individuals from all parts of the 'South', as government representatives or international agency officials or civil society campaigners. We see, however, in the crafting of a detailed SDGs specification and an agreed package, not just an insurgent 'South' but the importance of transcending blocs.

\section{Transitioning from the post-World War II order}

The United Nations system was established by the victors of the Second World War, especially the United States. We must distinguish, in the words of the UN Intellectual History Project, three 'United Nations': first, the intergovernmental forum, consisting of the General Assembly, Security Council, and other standing Councils and the comparable entities for each of the UN special agencies; second, the international administration, in the headquarters secretariat and the special agencies; but also third, the global publics and worlds of organizations and resource persons who seek to inform and persuade the governments and secretariats and to additionally represent 'We the peoples', the phrase used in the UN Charter (Jolly, Emmerij, and Weiss 2009). Permanent ambiguities and tensions have existed concerning the statuses and relations of these three spheres. Especially the third has grown in recent decades.

The United States and to a great extent the UN's other founding Great Powers have viewed the intergovernmental forum as purely a consultative and support body, a 
successor to the grouping of allies and friendly neutral countries that the US had formed under that name ('the United Nations') during the Second World War. The post-1945 global order ensconced an American veto and/or American predominance in international governance systems. The US, assisted by the UK, typically determined what emerged from global negotiations and what did not; these insider allies still for example blocked inclusion of corporate environmental responsibility in the instruments for follow-up of the Rio 1992 Earth Summit (Dodds, Laguna-Celis, and Thompson 2014). For most of that period the G7 (the US, UK, France, Germany, Italy, Japan and Canada) still formed a de facto global Cabinet. They perceived themselves as qualified and entitled to decide. Some other countries by contrast, and many civil society organizations and others, have increasingly wished to treat the intergovernmental forum, in full conversation with 'the Third UN', mentioned above, as the authoritative global forum, embodiment or voice of 'We the peoples'.

Over time, tensions in this post-1945 system of global governance grew, as the number of member countries increased, conformity within blocs declined, and members advanced in capacities and self-confidence. In addition, the strength and involvement of non-government actors - business, civil society, and non-profits, all typically linked in global networks - grew extraordinarily, amplified by new systems of communication. The conventional UN negotiation format, with all governments involved in word-by-word disputation around a draft from the UN bureaucracy, had by the new century become virtually unworkable (Kamau 2018). Kofi Annan as UN Secretary General (1996-2005) had the skills and moral stature to still use some windows of opportunity. But the MDGs over whose introduction he presided were largely a product of Northern donor countries, via the OECD, the World Bank, and the UN Secretariat. They achieved centrality because official development assistance was still decisively important for many countries; by 2012-2015 it was manifestly much less so.

The financial crisis that began in 2007-2008 reduced G7 authority and was a trigger for several shifts. Kamau, Chasek, and O'Connor (2018) describe the soaring self-belief felt by 'emerging market' economies, that in contrast to during their 1997-1998 financial crisis had now accumulated huge reserves. The South would no longer accept a Northern-set global development agenda. After the 2008 financial crisis, it was instead the North that had to cut back. The Copenhagen COP in 2009 highlighted the collapse of the tradition of multilateral negotiation dominated by the North. Powerful new players from the South were determined to block such practices, as China, India, and Brazil did at Copenhagen. But a mass of other South players were no longer willing to accept deals cooked by

only a small insider alliance, whether old or new (Kamau, Chasek, and O'Connor 2018). Increasingly assertive Latin American nations, often acting in concert, used opportunities provided by chairing the General Assembly or hosting a major UN event to harness energies from all three UN worlds. Using spaces widened by Annan, they activated the General Assembly's coordinating role across multiple agendas and agencies and the Economic and Social Council (ECOSOC)'s role in coordinating discussions of sustainable development and the environment (Dodds, Laguna-Celis, and Thompson 2014).

\section{Establishing and steering Rio+20 and injecting the SDGs notion - Brazil and Colombia}

The idea for a Rio+20 global summit conference came from Brazil in 2007, with stress on an agenda that would take 'sustainable development' seriously, covering both 'people' and 
'planet'. It gained approval in 2009, through support from the $\mathrm{G} 77$ and active interest of other groups such as ALBA (the association of Bolivarian states) and the association of Small Island Developing States. The US government lobbied to restrict Rio+20 to a small event, but lost control of the agenda (Dodds, Laguna-Celis, and Thompson 2014). Key figures in preparation, management and follow-up of the 2012 conference came from the South: the Pakistani Tariq Banuri, champion of 'Sustainable Human Development' in the 1990s, was director of the preparatory Secretariat; and Sha Zukang, Chinese head of the UN Department of Economic and Social Affairs (UNDESA), authorized ongoing open publication online of all important conference materials (Dodds, Laguna-Celis, and Thompson 2014). Just as geopolitics had evolved beyond the G7, so global diplomacy at a personal level appears marked by new generations of highly educated, experienced LDC participants, moulded in various cooperative international processes.

Vital for the commitment to SDGs at Rio+20 were two states: Brazil, the host and chair, who provided central steering, and Colombia, who provided the unifying idea. Their cooperation drove the train and recruited many allies and passengers. As of early 2012 preparations for the summit - negotiating through plenary sessions of 190-plus-countries and innumerable uncoordinatable side-channels - were in trouble (Kamau, Chasek, and O'Connor 2018). A coordinating idea-cum-vision was required, but the 'green economy' theme offered by the UN Environment Programme (UNEP) and backed by rich Northern countries was widely resisted, seen as a plot to block Southern industrialization or as importing economism into Human-Nature relations. The SDGs notion, tabled in 2011 by Colombia without much impact, attracted new attention. In response to the call for suggestions for the Rio+20 and post-2015 agendas, Paula Caballero, a Colombian government official, had proposed a broadened MDG-style set of goals: for sustainable development comprehensively conceived and, correspondingly, for the whole world:

I was concerned that the entire Conference was to focus on green economy - a concept mired in controversy - and a new international [organizational] architecture for sustainable development.... neither had the potential for incentivizing the deep transformations at scale so urgently needed. (Caballero 2016, 1)

The Colombian government adopted Caballero's proposal, but it initially received little support. Many people felt that SDGs would lose the MDGs' priority to developing countries and the poor. Colombia answered that poverty goals could never be achieved and sustained without attention to global boundaries and interconnections. Asked too 'Why is Colombia trying to lead on a global agenda?' it replied: we are a global 'bridge builder' (Caballero 2016, 2). It acted accordingly; for example, Caballero and her Minister went to Delhi in March 2012 to successfully persuade a key doubter, the Indian government.

The SDGs idea to (re-)integrate development and environment agendas gained sufficient backing to enter the negotiating text for Rio+20. Brazil itself had wanted to create a son-of-MDGs plus separate SDGs, but as conference chair it now adopted the proposal that had gained momentum. Its forceful yet inclusive chairing of the conference brokered an agreement out of the jaws of defeat (Kamau, Chasek, and O'Connor 2018). The Brazilian chair repeatedly announced that 'If there is no agreement then we have no alternative' but that 'the chair takes the pen' (Caballero 2016, 15). This decisive style allowed the discussion to become focused on a single text at each stage not a forest of competing redrafts, within a tight schedule set by the imminent arrival of heads of 
state. Formal approval was achieved for The Future We Want document (UN 2012) that, while including much talk of 'green economy' and much reiteration of previous declarations, culminated in a plan to create a new set of goals from 2015, now for all countries and integrating environment and development, taking over from the MDGs.

\section{Establishing and managing a process to specify SDGs}

Vitally, the conference outcome included a decision on follow-up. After days of negotiation, Brazil came down on the side of G77's choice for an extended open negotiation of SDGs via the General Assembly, not only prior drafting within the UN bureaucracy or by a special commission of 'the great and the good', and steered this through to adoption, despite strong resistance in many corners (Caballero 2016; Kjørven 2016). The eventual report of the separate great-and-good High Level Panel of Eminent Persons of 20122013 fortunately then recommended a variant of the SDGs idea, but was not used as the authoritative basis for their elaboration. Instead, that role was acquired by the Open Working Group (OWG) appointed by the General Assembly that began work well before the High Level Panel reported. As Northern powers and the UN Secretariat gradually came to realize, the SDGs initiative had been irreversibly taken over by the General Assembly. Article 81 of The Future We Want meant what it said: 'We further reaffirm the central position of the General Assembly as the chief deliberative, policymaking and representative organ of the United Nations.' 'We' here meant the majority of the member-states, operating with the principle that 'Responsible sovereignty is ... a necessary condition for States to cooperate in creating the conditions for the realization of internationally recognized rights and freedoms' (CDP 2014, 58). States will accept responsibilities if their sovereign right to interpret them is respected.

During 2012-2015 it became clear, step by step, that the SDGs as formulated by the OWG would be the main part of the post-2015 agenda, not a parallel or competitor exercise (Kamau, Chasek, and O'Connor 2018, 212). The OWG proceeded at majestic and deliberate speed, spending all of 2013 on detailed public stocktaking, followed by negotiation of an SDGs draft in the first half of 2014; building such a degree of consensus and momentum that rich countries that had hoped to renegotiate during the next stage found themselves isolated (Kamau, Chasek, and O'Connor 2018, 213). The OWG report (United Nations 2014b) was adopted by the General Assembly as the main basis, not just one input, for the inclusion of SDGs as centrepiece of the post-2015 agenda. The marriage of two huge policy trains, both with many long ensconced occupants - the Rio sustainable development agenda, now led by the General Assembly and G77, and the fuller post-MDGs ('post-2015') agenda, coordinated by the UN Secretariat - was successfully finessed (Kamau, Chasek, and O'Connor 2018, 99ff).

A major Southern presence continued within the OWG. African nations had mobilized successfully to obtain an African co-facilitator; and Kenya moved to profile itself through this position (Kamau, Chasek, and O'Connor 2018, 59-61). Southern-origin resource persons were much used in the stocktaking sessions throughout 2013, and made an impact (80-1). Colombia remained very active during the unusually long, intense, and open deliberations, as part of a coalition including many European partners (e.g. the traditional Nordic progressives, Switzerland, and Hungary, which provided the second of the two co-facilitators), and, for example, Indonesia, Kenya, and Pakistan (Kjørven 2016, 9). Similarly, in the subsequent process during 2014-2015 to get an agreement in the full 
General Assembly, actors from the South and from outside the traditional big players had vital roles. Ambassador Kamau was reappointed co-facilitator; Uganda headed the General Assembly for 2014-2015; and South Africa headed the G77 for 2015 (Kamau, Chasek, and O'Connor 2018). Their closeness helped in surviving a series of challenges, notably from many developed countries eager to reopen issues concluded on by the OWG. The G77plus-China very largely refused this, fearing that the whole elaborate compromise could then explode.

So far we have sketched a 'rise of the South' expressed in the SDGs agenda; something significant in terms of political psychology and for wider credibility of the agenda. Next we argue that this was not primarily a bloc-chauvinism, but part of moves towards a somewhat less divided, more open world. The SDGs process relied on a loosening of blocs, not only a rise of countries in the South.

\section{... and breaking open the blocs; to consolidate the emergent global public domain}

The SDGs needed to be seen as a shared global agenda, a consensus of the General Assembly not a Southern power-grab. To generate sufficient support and commitment for the conception, several procedural innovations contributed. The Open Working Group was a divergence from the UN tradition of assemblies of nearly 200 countries, usually bunched into blocs (often the US and its closest allies; the EU; the G77-plusChina; oil-producers; and various others), deliberating and frequently failing to agree on draft texts emergent from the UN bureaucracy. Here instead a working group from only 30 countries was asked to do the work but to be open in its discussions and open to representations. Following Rio+20, months of negotiation established that the 30 would be drawn roughly equally from the UN's five regional groups (with slightly more for Africa and Asia) but failed to bring agreement on which countries. Farrukh Khan, a Pakistan delegate in New York, devised a solution: two to four countries could form a joint delegation and share a seat (Kamau, Chasek, and O'Connor 2018, 53). Such groups were known as 'troikas' since many contained three countries. As a result 70 countries directly participated.

Compared to having 193 countries seeking to be heard and thereby frequently operating via the traditional rigid blocs mentioned above, the thirty 'troikas' system had interesting implications, especially since they continued for almost a year and a half and left a legacy. First, the old blocs such as the G77 and EU were downgraded; second, there were now nineteen voices largely from the South, out of thirty, rather than just one G77 position; third, many troikas combined EU and non-EU countries and/or countries of radically different income levels, which promoted mutual listening and learning, and formation of some longer-term partnerships (Kamau, Chasek, and O'Connor 2018); and fourth, the delegates in New York regained a negotiating role, rather than being reduced by modern communications to mere mouthpieces of their national capitals (Dodds, Donoghue, and Roesch 2017).

Managing this complex multilateral negotiation were two 'co-facilitators', de facto cochairs who learnt how to use the new room for manoeuvre. They were chosen from countries (Kenya, Hungary) unthreatening to others yet with substantial capacity. They made sure that they kept the confidence of their 'own' original North/South macro-bloc 
but that they represented not only that bloc and were seen to show sensitivity to the concerns and political pressures in each major country and group, to work in close coordination with each other, and to stand for the integrity and effectiveness of the process and the interests of 'people and planet' (Kamau, Chasek, and O'Connor 2018).

Let us consider further the modus operandi used in the OWG to try to construct a global alliance for SDGs: open public communications; 'parallel thinking' to work towards a sufficiently shared vision; and leaders who consulted exhaustively but 'kept the pen'.

\section{Mechanisms and dynamics in building a new global agenda}

'We will do business differently ...' (Kamau 2016).

\section{Open communications across and with the world}

By 2011-2012 it was evident, except to some old elites recollects Kjørven $(2016,3)$, that one could not repeat the MDGs procedure wherein a small group specified a global agenda behind closed doors. The rise of the South, of civil society organizations and networks, and of electronic options for global deliberation, plus the West's financial crisis, had rendered such procedure obsolete. From the start, Colombia involved and cooperated with major NGOs to strengthen its SDG campaign (Caballero 2016). Already in November 2011 a consultation in Bogotá involved a variety of governments and non-government actors and initiated an SDGs alliance. Without such links, the SDGs would have been seen as a Colombian or at most a Latin American bid for attention. A larger meeting in early 2012, supported by the World Resources Institute, carried the campaign into the pre-Rio+20 negotiations at the UN. All eighty participants sat around one table, which 'created a sense of purpose and openness' (Caballero 2016, 8).

The vision of open communication was maintained. Dodds, Laguna-Celis, and Thompson (2014) report that the Stakeholder Forum served as an effective one-stop website for all non-government stakeholders in the Rio+20 preparatory process. For the post-Rio stage, the Open Working Group's terms of reference made a commitment to 'openness, transparency, inclusiveness, and consensus' (Kamau, Chasek, and O'Connor 2018, 56). Ambassador Donoghue refers to

the remarkable process of global public consultation, conducted over the couple of years [2012-14] prior to the [2014-15 inter-governmental negotiations]. This process was unprecedented in its scale and breadth. It gave negotiators from all member States a vivid sense of the importance of these negotiations and the responsibilities and expectations attached to them. It also brought out very clearly the consensus around the world that the new goals and targets should reflect a high degree of ambition and should be truly transformational, representing a clear step-change. (Donoghue 2016, 4)

To Kjørven's surprise, the WorldWeWant2015 portal produced not Babel but clear patterns, including emphases on elements of the 2000 Millennium Declaration that the MDGs had omitted, 'especially freedom from violence and fear, and responsible governance' $(2016,7)$.

During the OWG negotiations, only accredited non-government stakeholders could participate, and could only observe sessions. However, the co-chairs consulted them. They convened regular open meetings with the non-government Major groups (the 
stakeholder fora recognized by the UN that have consultation rights). Almost no government delegates joined, but the materials were put on the website and the co-chairs found many of the ideas helpful. They recognized too that for later action the commitment of civil society would be vital (Kamau, Chasek, and O'Connor 2018, 125 ff.).

The OWG sessions were webcast; and their stately pace over a year and a half encouraged continuing work in a maze of arenas of consultation and lobbying - per theme, within countries, via stakeholder groupings, and more (summarized by Dodds, Donoghue, and Roesch 2017, 56). Informal discussion arenas in this case built trust and crossed borders; e.g. for each thematic area a 'Friends of ...' group existed in UN circuits, and the World Resources Institute organized many confidential fora.

The subsequent stage of intergovernmental negotiations through the General Assembly from November 2014 to July 2015 involved many new people, but much of the OWG's openness, post-blocs spirit, and flexibility is reported to have continued. The co-facilitators were granted coordinating authority; the post-2015 Agenda was acknowledged as so important that individual countries could speak, not only through blocs (Donoghue 2016, 2); and the unusual degree of mingling of government delegations and intergovernmental agencies with non-government stakeholders even intensified: member-state representatives began to mix with civil society in the additional informal consultation sessions (Donoghue 2016, 5; Kamau, Chasek, and O'Connor 2018, 222-223). According to Donoghue, strong civil society involvement kept the level of ambition and technical quality high $(2016,7)$. By the final negotiation days in July 2015, the participation of the non-government Major stakeholder groups ran so easily that there was no $G 77$ request to remove them from the hall, unlike in previous large UN negotiations (Dodds, Donoghue, and Roesch 2017). Two years of interaction had increased mutual acceptance and respect, plus the non-government actors felt no need to exert last-minute pressure, for they had enjoyed ample space to participate (Donoghue 2016).

\section{Parallel thinking - the white hat: building sufficient shared global vision}

The OWG co-chairs rejected the usual UN procedure of inter-bloc debate ad nauseam of competing draft texts. Instead, to the astonishment of many, they allocated almost a year to 'stocktaking': a process of consciousness-raising, trust-building, and upgrading the knowledge base of perhaps most delegations, starting from less controversial topics (Kamau, Chasek, and O'Connor 2018, 71ff). One sees an analogy to James Fishkin's system of 'deliberative polling' - moving to debate and decisionmaking only after a long dispassionate briefing-and-questioning phase (Fishkin 2011) - and Edward De Bono's 'Six Hats' approach (1994, 2000), which requires a demarcated 'White Hat' phase of cooperative information-gathering and sifting. Eight multi-day meetings were held in New York through 2013 and the start of 2014, over a total of 29 days. This format encouraged continuity of participation by New York-based national teams, while giving them time to liaise back home and learn too from the numerous inter-sessional events, often organized through the President of the General Assembly. The stocktaking sessions established a frame of taking responsibility for global problems, and a feeling that countries would themselves determine the direction, not be dictated to by closed expert groups or specialist agencies (Kamau, Chasek, and O'Connor 2018, 75-76). According to 
Kjørven, the OWG became 'open and deliberative' $(2016,9)$, not a standard arena for reading-out statements and criticizing others but a group for shared thinking and learning.

The long preparatory phase created a sufficient common awareness of the magnitude and seriousness of what was being addressed and the advances that could be made through feasible responses; it established a de facto working global alliance, not just partisan alliances. So in final negotiations on the OWG's report, faced with the choice between using a veto on one's favourite topic where one had not got all that one wanted or instead accepting an overall worthwhile package-deal, every country chose the latter (Kamau, Chasek, and O'Connor 2018, 155-160). For example, in classic UN style, the night before the final session 'a powerful country' brought new demands. It was told by Kamau and the head of the UNDESA secretariat that this was too late but that it was free to make its demands in open session during the final meeting; it did not. A similar last moment insurrection arose from countries objecting to language on sexual and reproductive rights. They were reminded that all SDGs remain subject to a country's choices during implementation, but that they had the option to veto the text publicly and be judged by the rest of the world. The insurrection fizzled out.

\section{The blue hat: understanding and managing the cast of characters and 'keeping the pen'}

Important in the 2013-2015 negotiations were bilateral South-North alliances, including between the co-chairs (Kenya-Hungary, later Kenya-Ireland) and the connections that these facilitators maintained with diverse other players and alliances, so that they could judge what compromises would be plausible. Kamau, Chasek, and O'Connor (2018, 107-119) distinguish a series of country groups in the OWG: those in sympathy with the SDGs concept and spirit, such as Colombia, France, Germany, Guatemala; 'the Conservatives', such as Brazil, China, and India, preoccupied with enforcing greater responsibilities for richer countries and ensuring their own right to pollute first and clean up later, as the rich had done; 'the Ultra-conservatives', like Saudi Arabia; and particular issuecoalitions, like the Bolivarian Alliance (ALBA) whose emphasis on Mother Earth was taken into account and respected.

To maintain a focus on big issues during the final five multi-day OWG sessions, reserved for formal negotiations, and to avoid the traditional descent into word-by-word warfare, the co-facilitators retained for themselves and their secretariat the prerogative of drafting and re-drafting ('Holding the pen'; Kamau, Chasek, and O'Connor 2018, 146ff.). They provided frequently updated drafts that aimed to demonstrably reflect the balance of the open-access discussions. This avoided public contestation between jealously defended amendments from specific delegations, the normal practice. The co-chairs refused all requests to switch to on-screen negotiation of text, the traditional format. The refusal was politically sustainable only through their being constantly available and interactive and retaining the trust of delegations and governments. By circulating a 182-page compilation of all proposed amendments they showed delegates that suggestions were recognized, but also the absurdity of switching to such a document as the focus for negotiation. In De Bono's terms, the co-chairs wore the 'Blue Hat', determining the sequence and schedule of topics of discussion while ensuring that each stage involved the participants 
working 'in parallel': focused on the topics and not on each other, with no sub-group 'ownership' of competing draft texts. They declined to delegate negotiation of particular difficult issues to assigned sub-groups or mini-alliances, for that would jeopardize broadly-shared commitment, overall intellectual coherence, and the chairs' ability to suggest cross-issue deals.

In this way, the extraordinary number of issues under discussion could be managed. Indeed the sheer number gave more scope for making deals, provided that the chairpersons retained authority and trust, and provided they and their team had listened enough to identify both the no-go zones and possibilities for compromise. Kamau, Chasek, and O'Connor (2018) supply numerous examples from the 2014 climax of OWG negotiations. They found too that having an extensive Introduction section ('chapeau'), that presented preamble, context, and broad approach prior to the goal-by-goal texts, provided a useful 'protective belt' where many points dear to particular participants but disputed by others could be placed (for example, the principle of Common But Differentiated Responsibility).

While the negotiations during 2015 to write the post-2015 agenda document were in some ways more openly and traditionally political (Kamau, Chasek, and O'Connor 2018, $217 \mathrm{ff}$.), they retained several features of the OWG. Crucially, the two co-facilitators 'kept the pen'. They could thus more readily find late-stage compromises; draft an inspirational if non-binding introductory Declaration that presented the themes of People, Planet, Prosperity, Peace, and Partnerships; and traverse the swampy territory of principles of accountability by adopting G77's language of voluntary, nation-state centred but still open and participatory 'reporting and review' that would retain weight through requiring presentation of the reviews to periodic High Level Political Fora of the UN. Remarkably, the negotiation process was concluded on time, several weeks before the heads-of-states summit that confirmed approval.

\section{Communication again}

The next stage in building alliances began immediately: to communicate the SDGs to publics and organizations worldwide (Kamau, Chasek, and O'Connor 2018, ch. 9). The SDGs were produced by far fuller consultative processes than for the MDGs, and were led by national governments not international bureaucracies, so they were launched with already a fuller awareness from insider stakeholders; but reaching wider publics requires more. The now familiar visual icons were devised by filmmaker Richard Curtis and a Swedish company. Some Voluntary National Reviews have already been prepared or are underway, to be sent to the annual High Level Political Fora on Sustainable Development. Various NGOs are preparing SDG progress reports. Compared to the MDGs, more businesses hope for profit by linking to SDG language and/or agendas (say, for reducing food waste), and in having their SDG-contributions monitored and publicized.

One factor should be added to the accounts of the SDGs process. Having sufficient time, including thanks to the happy coincidence that three years remained between the Rio anniversary in 2012 and the expiry of the MDGs period in 2015, proved vital for the processes of learning, trustbuilding and negotiating. Time alone would have been useless though without the sorts of methods and mechanisms mentioned above. 


\section{What is the potential of the SDGs?}

What are the content qualities and potentials of the SDGs generated by these processes? Many authors point out weaknesses, especially in the targets and indicators (e.g. FukudaParr and McNeill 2019). However, part of the potential of the SDGs derives from their form - as norms that have a public education role, articulated in a goals-targets-indicators framework with scope for national level adjustments and additions - and from ongoing investments in building systems for cooperation.

\section{Paper tigers? Shortcomings in contents}

Within technocratic and Northern establishment policy communities, the SDGs have been frequently dismissed as a rhetorical Babel; surfeit of goals and targets meant no real goals and targets. Browne (2017) declares this, for example; yet he also attacks the SDGs for neglecting migration, capital flight, terrorism, conflict, democracy, and so on. Caballero and Kjørven, in contrast, argue that to have more goals than the MDGs' eight was vital for achieving broad appeal; and the fact that only seventeen emerged, compared to the ocean of proposals, was remarkable.

For many commentators, the gallery of worthy goals is vitiated by fundamental omissions. First, non-recognition of planetary boundaries. Brandi (2015) sees cognizance of only two of six such 'guard rails'; Camacho (2015) notes silence on population growth; and Palmer (2015a) and Browne (2017) criticize the adherence to a 'three pillars' notion of sustainable development that retains as a first pillar an unreconceptualized economic growth. There is no commitment to replace the disastrous use of GDP as a measure of progress (Stewart 2015). Instead the 2030 Agenda, like 2012's The Future We Want, constantly reiterates 'economic growth' - for all countries, even the already super-affluent, to continue without end. Second, the SDGs do not seriously address problems in rich countries (e.g. what do poverty and malnutrition distinctively mean in these countries); nor, third, do they seriously address inequality, a key driver of problems in all fields (Vandemoortele 2017). Fourth, the set lacks an explicit, motivating, disciplining ethical basis. ${ }^{3}$ Fifth, no clear responsibilities are assigned, especially to those who are responsible for the current state of global systems (Pogge and Sengupta 2015) and who have responseability (Fukuda-Parr and McNeill 2015).

Arguably, these commentators miss some dimensions central to polycentric global governance. The goals-targets-indicators framework can contribute in capturing and focusing attention and energies, and in encouraging commitments cascades; but it is not intended to provide a globally enforced blueprint (Kamau 2017). Stewart (2015) fears that the goals are too universally generalized; but their status is as advisory, and national responsibility allows the nation-specific refocusing she calls for. To combine mobilization and intelligent flexibility will partly depend on the quantity and quality of responses by national and global civil society. Further, processes of impact will not occur in one smooth stage, for they unfold in interaction with often-problematic established power-structures. As in the human rights cascade model, change will happen in phases, punctuated by crises. The role of the SDGs as a normic framework is not only to guide phases of relatively straightforward gains but also to help mobilize forces for change, that, given suitable preparation, can respond effectively during the crises. 


\section{Progress through goals-targets-indicators (G-T-I) and nation-specific adaptations}

The rationale of a G-T-I framework is political as well as technical. Whereas the 1992 Rio conference's Agenda 21 rapidly lost impetus (Kamau, Chasek, and O'Connor 2018), the goals-and-targets format of the MDGs a decade later helped make them memorable and actionable (Pronk 2015), allowing the UN to capture attention, focus discussion, and regain a coordinator role. Kjørven recounts how he like many others originally had no time for the simplistic-seeming MDGs, but found in practice that they had a valuable coordinating function $(2016,2)$. The focused, shared attention was not only from development managers and aid officials but from politicians and publics. Browne notes thus that while MDG contents were nothing special or new, their presentation and targetization contributed to heightened public support in the North for development assistance, and to the 2002 Monterrey commitment to provide more financial support for the specified ends - unusual in that it was so substantially fulfilled $(2017,98)$.

Reflecting that the MDGs were donor-tools, they had much less public profile in the South. In contrast, the SDGs have been prepared with more consultation and launched more rapidly and widely, propelled by the now ubiquitous icons and by framing in 'a "we the people[s]" document, rather than using only a state-centric approach. [Their] achievement will [depend on] their ability to inspire people around the world' (Dodds, Donoghue, and Roesch 2017, 128). Palmer's concerns that the end of the OWG marked the end of global consultation seem misplaced - the genie is out of the bottle (2015b).

The G-T-I framework is meant to allow a combination of big vision, feasible foci, and nationally-specific adaptations. Vandemoortele (2017) warns that only 30 of the 169 SDG 'targets' as formulated in 2015 were clear, time-specific, and quantified; Browne (2017) and others correspondingly condemn the goals as not a helpful management tool. Arguably however, the SDGs are not to be judged by technocratic tidiness, as if they were MDGs 2.0 for coordinating the work of a set of controller international funding agencies. Instead, in a different historical era compared to at the turn of the millennium, the criterion is how far they can inspire efforts and creativity from innumerable diverse agents worldwide.

To inspire and mobilize, national-level character and flexibility are important. During the MDGs this was ignored by donors, records Vandemoortele; for example Vietnam and Cambodia produced their own MDGs sets which foreign funders bypassed. But the SDGs are not a donor-centred exercise; they must play a mobilizing role within national societies, not only for international funding agencies, and this requires meaningful nationally-specific targets and indicators. In early 2015, principles of national ownership and intra-national disaggregation were agreed for the indicators framework (Dodds, Donoghue, and Roesch 2017, 123ff.). This came at member-state insistence and on advice from the UN's expert Committee on Development Policy, to acknowledge 'the diversity of national circumstances and policy approaches - a diversity which should be embedded in the architecture of global governance as an intrinsic feature of the global community, not as an exception to general rules' (UN 2014a, vii).

More can be said about shortcomings of the existing global list of indicators, but if nationally-led processes are central these indicators are not the heart of the matter (Kamau 2017). A non-binding flexible framework may be more productive in situations 
where the actors whom one seeks to influence are not cowed mistrusted dependents but instead resourceful and wilful agents (Biermann, Kanie, and Ekima 2017). National-level flexibility need not mean dilution of targets and indicators if civil society is well mobilized. In such situations seeking to disseminate inspiring norms that indicate directions, rather than to impose standard world targets, can be sensible.

\section{Norm diffusion and corporate commitments cascades}

Browne suggests that the UN development system has had four roles. First, to provide research, data, and information; second, to undertake projects and provide technical assistance. In these areas, the UN is now a small actor compared to others, but it remains central and indispensable in the two other roles: third, development of norms and technical standards, and associated monitoring; and fourth, preparation of global policy and conventions, and related awareness-raising. He plausibly proposes that the SDGs are best seen as a norm-setting agenda (2017, 143-144), which fits 'the world 'beyond aid' (138), and should be conceived in a bottom-up, human development format more than a topdown technical sector-oriented format. Ruggie had similarly pointed out that given 'the emergence of a global public domain beyond the sphere of states' $(2004,509)$, in which social movements, local governments, NGOs and companies participate, norms such as human rights and SDGs are vitally important. This holds true both when the actors involved genuinely internalize them or only adopt them to maintain public respectability.

Norms can influence behaviour through communicating values and setting criteria for international and intra-national comparison, legitimacy, and respectability; while yet being compatible with different underlying value-theories and allowing flexibility in interpretation and choice of means. Correspondingly, well-designed international norm sets can sometimes call forth greater response than do more precise and purportedly universal binding rules or a system of pure national-level self-determination. This may apply still more strongly in seeking to influence businesses. Dodds, Laguna-Celis, and Thompson (2014) highlights, for example, the Registry of Voluntary Commitments initiated after the Rio+20 Corporate Sustainability Forum and the Dialogue Days with Major Groups and other stakeholders. Seeking legitimacy and favourable publicity, a mega-corporation like Microsoft declared there that it would go carbon-neutral. A set of 37 financial sector CEOs agreed to a Natural Capital Declaration, to gradually implement natural capital impact disclosure, respect for biological diversity, and so on. Such a declaration provides a basis for subsequent monitoring and lobbying of those corporations by a Corporate Sustainability Reporting Coalition.

\section{Building systems, not only 'alliances'}

A successful global system of norm generation, diffusion, adaptation, application and extension cannot exist in the abstract, but must be embodied in organizational and institutional systems. Most observer NGOs and radical journalists were disappointed by the outcomes of the Rio 2012 Summit - its lauding of economic growth, its lack of decisive binding commitments, its inevitable political vagueness and compromises. But, claim Dodds, Laguna-Celis, and Thompson (2014), Rio+20 reflected and contributed to fundamental shifts in 'architecture': a move away from dominance by Northern governments; 
an enormous increase in business and especially global civil society involvement, linked to the explosion in global 'connectivity'; and a reinvigoration of parts of the UN system, rendering it more capable to support follow-up than after the 1992 Rio Earth Summit or the Millennium Declaration of 2000. For much of the 1992 Agenda little follow-up happened, partly due to UN fragmentation. An important change made around 2012 was the abolition of the ineffective Commission on Sustainable Development and the revival instead of ECOSOC as a key UN organ, for integration across the supposed three sustainable development pillars (economic, social, environmental), backed up by periodic High Level Political Fora. A second significant change was reform and revival of UNEP, to establish it with universal membership, a broader mandate and more senior permanent national delegations.

Equally important as intergovernmental systems are global civil society systems, to place pressure on the governmental and intergovernmental structures. This applies strongly in the current era as neglected issues surface and interact: critical environmental problems, the backwashes from marginalization of many groups and countries, and the rise of populist nationalism worldwide. Systems are needed too to keep societal stakeholder involvement itself honest and accountable. Dodds, Laguna-Celis, and Thompson (2014) and Dodds, Donoghue, and Roesch (2017) suggest relevant elements: methods for promoting popular participation in UN dialogues (UNDESA 2013); withdrawal of recognition from 'greenwashing' activities, and creation of an ISO standard for what are genuine multi-stakeholder partnerships; invigoration of National Councils for Sustainable Development, including to inform and energize parliamentary committees; and consultation arrangements that include young people.

\section{Conclusion - lessons and questions}

Important features of the Sustainable Development Goals include the following:

(1) The SDGs reflect 'the rise of the South'. Both the process and the outcomes have been strongly marked by views from the South, and so, for example, include stresses on national sovereignty and national-level flexibility. They form an attempt at relatively light but consensual coordination across a global system that is now less run from a global core.

(2) At the same time, the SDGs reflect in some ways a blurring of old North-South divisions. Kamau, Chasek, and O'Connor (2018) note a gradual evolution of the G77 beyond a focus upon obtaining concessions from the North. The SDGs emerged through a loosening of traditional blocs, not creating or reinforcing permanent partisan 'alliances' but through an informal working alliance for 'a world united'. Alliance appears here as an attitude not a closed partisan bloc. Such global alliance relies on some degrees of ambiguity.

(3) Besides the 'proliferating transnational ties and strategies among states themselves' (Ruggie 2004, 521), the strategies and ties among non-government actors and between states and these actors have become markedly more important, absolutely and relatively, as dimensions in polycentric global governance.

(4) Most of Murphy's (2005) list of elements required in progressive international reform were amply illustrated: wideranging networks, motivated by some unifying value- 
laden ideas embodied in practicable plans for action, and with good links to potentially sympathetic decision-makers. These bases for action still require skills in action; insider accounts of the SDG process stress the role of careful combinations of open deliberation, forceful cohesive chairing, and building not just 'alliances' but intra- and inter-organizational systems.

(5) Even when there are differences in underlying values, norms can sometimes be agreed to and can diffuse and exert influence. A goals-targets-indicators framework can help to catch and focus attention, including from national and global civil society; while national sovereignty allows country-specific adjustment, prioritization, and augmentation. Commitments may in some cases cascade; for example, from corporations hoping to build an advantageous profile and from governments or blocs that seek global leadership or inward investments. Monitoring this set of expectations and the actual outcomes forms a major research task ahead.

Additional questions arise for future work.

(6) What is the SDGs' ability to inspire people around the world? Can it grow over time as happened with human rights? Can they grow into a focus for mobilization concomitant with the scale and causations of the problems considered?

(7) SDGs are less of a Northern driven and controlled process than were MDGs. But will the South play equally important roles in the conversion of SDG themes and commitments into action?

(8) Of special interest for global ethics theory, how far does progress require a coordinating idea-cum-vision and how far does that require an explicit ethical base? Does one need to persuade privileged people that disadvantaging and sacrificing the poor, including mainly poor people in other countries, is not only imprudent but wrong? (Even more so in regard to sacrificing future generations, where pure prudence arguments cannot apply.) How far has the SDGs process relied on permeation and use of a shared global ethical Esperanto, perhaps a tacit mix of human rights and human needs thinking, or has it only involved conceiving 'win-win' deals, albeit with some enlightening of the perceptions of self-interest thanks to stakeholders gradually becoming more aware of interconnectedness, including of others' powers both to react and to cooperate?

There might be too little time left for much global value convergence before future global crises; hence instead a need to rely on whatever degrees of ethical Esperanto already exist, and on the sort of 'Getting to Yes' search for 'win-wins' that the SDGs negotiations partly illustrate. The literature on policy-related research suggests that perhaps most influence occurs via indirect channels over long time periods, including through re-framing and re-interpretation of questions and categories, rethinking what one's 'interests' are and even one's identity. No centuries of grace time remain, however, for us to be able to avert collapses of eco-systems through relying only on gradual social learning and a smooth trajectory of 'socialization'. Instead we should prepare for a series of crises and their knock-on effects, which could open windows for bigger socio-political shifts and fuller reconstruction of identities and values (Raskin 2016). The SDGs reflect a necessary early phase in that unfolding pathway of transition. 


\section{Notes}

1. See e.g. two special sections in the Journal of Global Ethics, 2015.

2. The 2030 Agenda contains several mentions of human rights in its Preamble and Introduction, but almost none in the presentation of the 17 SDGs. Donoghue (2016) notes that, even so, objections by some governments to human rights references continued through to the final morning of the 2015 negotiations. The other accounts of SDGs' emergence drawn on in this paper lack significant references to human rights.

3. A human security framework could serve to bring in such missing elements and integrate the various components, argue Köhler et al. (2012).

\section{Disclosure statement}

No potential conflict of interest was reported by the author.

\section{References}

Biermann, Frank, Norichika Kanie, and Rakhyun Ekima. 2017. "Global Governance by Goal-Setting: The Novel Approach of the UN Sustainable Development Goals." Current Opinion in Environmental Sustainability 26-27 (June): 26-31.

Brandi, Clara. 2015. "Safeguarding the Earth System as a Priority for Sustainable Development and Global Ethics." Journal of Global Ethics 11 (1): 32-36.

Browne, Stephen. 2017. Sustainable Development Goals and UN Goal-Setting. London: Routledge.

Caballero, Paula. 2016. "A Short History of the SDGs." April 29. deliver2030.org.

Camacho, L. 2015. "Sustainable Development Goals: Kinds, Connections and Expectations." Journal of Global Ethics 11 (1): 18-23.

CDP. 2014. Global Governance and Global Rules for Development in the Post-2015 Era. Committee on Development Policy. New York: United Nations.

De Bono, E. 1994. Parallel Thinking. New York: Viking.

De Bono, E. 2000. Six Thinking Hats. Revised ed. London: Penguin.

Dodds, F., D. Donoghue, and J. L. Roesch. 2017. Negotiating the SDGs. Abingdon: Routledge/Earthscan.

Dodds, F., J. Laguna-Celis, and L. Thompson. 2014. From Rio+20 to a New Development Agenda. Abingdon: Routledge/Earthscan.

Donoghue, D. 2016. "My Perspective on the SDG Negotiations." May 2016. deliver2030.org.

Finnemore, M., and K. Sikkink. 1998. "International Norm Dynamics and Political Change." International Organization 52 (4): 887-917.

Fishkin, J. 2011. When the People Speak: Deliberative Democracy and Public Consultation. New York: Oxford University Press.

Fukuda-Parr, Sakiko, and Desmond McNeill. 2015. "Post 2015: A New Era of Accountability?" Journal of Global Ethics 11 (1): 10-17.

Fukuda-Parr, Sakiko, and Desmond McNeill, eds. 2019. "Knowledge and Power in Setting and Measuring SDGs." Global Policy, Vol. 10, Suppl. 1. Open access: https://onlinelibrary.wiley.com/ toc/17585899/2019/10/S1.

Gasper, D. 2006. "What is the Point of Development Ethics?" Ethics and Economics/ La revue Éthique et Économique 4 (2). http://ethique-economique.net/Volume-4-Numero-2.html.

Gasper, D. 2007. “Human Rights, Human Needs, Human Development, Human Security - Relationships Between Four International 'Human' Discourses." Forum for Development Studies 34 (1): 9-43.

Gasper, D. 2016. "The Ethics of Economic Development and Human Displacement." In Oxford Handbook on Professional Economic Ethics, edited by G. DeMartino and D. McCloskey, 534-557. New York: Oxford University Press.

Gasper, D. 2019. "Insouciance, Indifference and Any Inspiration in the Face of Emergent Global Crises?" In The Pedagogy of Economic, Political and Social Crises, edited by B. Jessop and K. Knio, 209-228. London: Routledge. 
Jolly, R., L. Emmerij, and T. G. Weiss. 2009. UN Ideas That Changed the World. Bloomington: Indiana University Press.

Kamau, M. 2016. "Speech to UN Global Compact Leaders Summit, UN Headquarters." https://www. youtube.com/watch?v=xfwxOfx35GA.

Kamau, M. 2017. Speech to the Workshop on Knowledge and Politics in Setting and Measuring the SDGs. New York: New School University. November 20.

Kamau, M. 2018. "Foreword." In Transforming Multilateral Diplomacy: The Inside Story of the Sustainable Development Goals, edited by M. Kamau, P. Chasek, and D. O'Connor, xvii-xviii. New York: Routledge.

Kamau, M., P. Chasek, and D. O'Connor. 2018. Transforming Multilateral Diplomacy: The Inside Story of the Sustainable Development Goals. New York: Routledge.

Kjørven, O. 2016. "The Unlikely Journey to the 2030 Agenda for Sustainable Development." February 15. deliver2030.org.

Köhler, G., D. Gasper, R. Jolly, and M. Simane. 2012. "Human Security and the Next Generation of Comprehensive Development Goals." Journal of Human Security Studies 1 (2): 75-93.

Murphy, C. 2005. Globalization, Institutions and Development. London: Routledge.

OHCHR (Office of the High Commissioner for Human Rights). 2011. Guiding Principles on Business and Human Rights. Geneva: United Nations.

Palmer, Eric. 2015a. "Introduction: The Sustainable Development Goals Forum." Journal of Global Ethics 11 (1): 3-9.

Palmer, Eric. 2015b. "Introduction: The 2030 Agenda." Journal of Global Ethics 11 (3): 262-269.

Pogge, T., and M. Sengupta. 2015. "The Sustainable Development Goals: A Plan for Building a Better World?" Journal of Global Ethics 11 (1): 56-64.

Pronk, Jan. 2015. "From Post 1945 to Post 2015." Journal of Global Ethics 11 (3): 366-380.

Raskin, P. 2016. Journey to Earthland. Boston, MA: Tellus Institute.

Risse, T., S. C. Ropp, and K. Sikkink. 2013. The Persistent Power of Human Rights - from Commitment to Compliance. Cambridge: Cambridge University Press.

Risse, T., and K. Sikkink. 1999. "'The Socialization of International Human Rights Norms Into Domestic Practices: Introduction'." In The Power of Human Rights - International Norms and Domestic Change, edited by T. Risse, S. C. Ropp, and K. Sikkink, 1-38. Cambridge: Cambridge University Press.

Ruggie, J. G. 2004. "Reconstituting the Global Public Domain: Issues, Actors, and Processes." European Journal of International Relations 10 (4): 499-531.

Ruggie, J. G., 2008. "Protect, Respect and Remedy: A Framework for Business and Human Rights." Report to UN Human Rights Council, Geneva, A/HRC/8/5.

Ruggie, J. G. 2015. "Life in the Global Public Domain: Response to Commentaries on the UN Guiding Principles and the Proposed Treaty on Business and Human Rights." January 23. At SSRN: doi:10. 2139/ssrn.2554726.

Stewart, Frances. 2015. "The Sustainable Development Goals: A Comment." Journal of Global Ethics 11 (3): 288-293.

Sunstein, Cass. 1997. Free Markets and Social Justice. New York: Oxford University Press.

UNDESA. 2013. Strengthening Public Participation. New York: Division of Sustainable Development, United Nations Department of Economic and Social Affairs.

United Nations. 2012. The Future We Want. Outcome Document of the 2012 Rio+20 Global Summit on Sustainable Development. New York: United Nations.

United Nations. 2014a. Global Governance and Global Rules for Development in the Post-2015 Era. Committee for Development Policy. New York: United Nations.

United Nations. 2014b. Report of the Open Working Group of the General Assembly on Sustainable Development Goals. A/68/970. New York: United Nations.

United Nations. 2015. Transforming our World: The 2030 Agenda for Sustainable Development. New York: United Nations.

Vandemoortele, J. 2017. "From MDGs to SDGs: Critical Reflections on Global Targets and Their Measurement." In Sustainable Development Goals and Income Inequality, edited by P. van Bergeijk and R. van der Hoeven, 32-50. Cheltenham: Edward Elgar. 